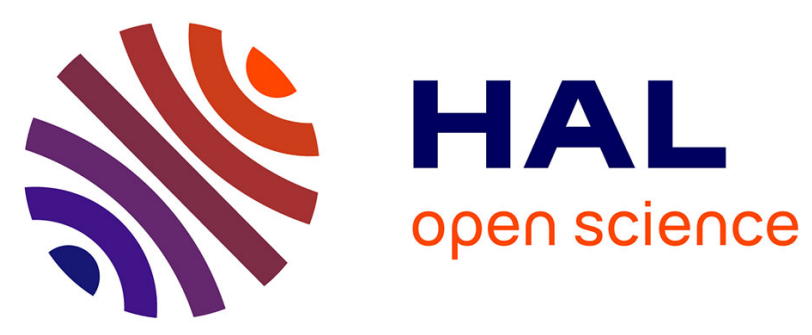

\title{
Development of a selective ammonia YSZ-based sensor and modeling of its response
}

\author{
Gita Nematbakhsh Abkenar, Mathilde Rieu, Philippe Breuil, Jean-Paul \\ Viricelle
}

\section{- To cite this version:}

Gita Nematbakhsh Abkenar, Mathilde Rieu, Philippe Breuil, Jean-Paul Viricelle. Development of a selective ammonia YSZ-based sensor and modeling of its response. Sensors and Actuators B: Chemical, 2021, 338, pp.129833. 10.1016/j.snb.2021.129833 . emse-03192932

\section{HAL Id: emse-03192932}

\section{https://hal-emse.ccsd.cnrs.fr/emse-03192932}

Submitted on 20 Apr 2021

HAL is a multi-disciplinary open access archive for the deposit and dissemination of scientific research documents, whether they are published or not. The documents may come from teaching and research institutions in France or abroad, or from public or private research centers.
L'archive ouverte pluridisciplinaire HAL, est destinée au dépôt et à la diffusion de documents scientifiques de niveau recherche, publiés ou non, émanant des établissements d'enseignement et de recherche français ou étrangers, des laboratoires publics ou privés. 


\title{
Development of a selective ammonia YSZ-based sensor and modeling of its response
}

\author{
Gita Nematbakhsh Abkenar, Mathilde Rieu*, Philippe Breuil, Jean-Paul Viricelle \\ Mines Saint-Etienne, Univ Lyon, CNRS, UMR 5307 LGF, Centre SPIN, F-42023, Saint- \\ Etienne, France. \\ * Corresponding author: M. Rieu. E-mail: rieu@emse.fr
}

\begin{abstract}
In the present study, $\mathrm{Au}-\mathrm{V}_{2} \mathrm{O}_{5}$ sensing material was tested as a sensing electrode for developing mixed-potential ammonia gas sensors. The results of gas sensing measurements indicated selective responses to $\mathrm{NH}_{3}$ while this selectivity was highly dependent on the temperature. Different $\mathrm{V}_{2} \mathrm{O}_{5}$ contents were tested in the sensing electrode. The results showed that by increasing $\mathrm{V}_{2} \mathrm{O}_{5}$ content from $15 \mathrm{wt}$ \% to $50 \mathrm{wt} \%$, selective ammonia sensors could be achieved at $550{ }^{\circ} \mathrm{C}$. The selectivity of $\mathrm{Au}-50 \% \mathrm{~V}_{2} \mathrm{O}_{5}$ sensor was also confirmed in gas mixtures of $\mathrm{CO}, \mathrm{NH}_{3}, \mathrm{NO}$, and $\mathrm{NO}_{2}$ gases. Modeling of the sensor responses in the ammonia concentration range 2-40 ppm at four oxygen concentrations was performed based on mixedpotential theory. Nernst and Butler-Volmer equations with an electron transfer assumption were used for data modeling.
\end{abstract}

Keywords: Mixed-potential gas sensor, Ammonia, Sensing electrode, $\mathrm{V}_{2} \mathrm{O}_{5}$, Response modeling.

\section{Highlights}

High temperature ammonia gas sensors were studied.

$\mathrm{Au}-\mathrm{V}_{2} \mathrm{O}_{5}$ sensing electrode was sensitive and selective to $\mathrm{NH}_{3}$.

Gas sensor responses were modeled according to mixed potential theory. 


\section{Introduction}

Selective catalyst reduction (SCR) system using ammonia gas as a reductant is one of the most reliable ways to reduce $\mathrm{NO}_{\mathrm{x}}$ emissions from diesel engine vehicles and trucks. To optimize the conversion rates of $\mathrm{NO}_{\mathrm{x}}$ and to prevent inducing excessive $\mathrm{NH}_{3}$ to the air, an ammonia sensor is required to control the SCR system [1]. There are wide ranges of studies in the literature to find a robust, sensitive, low cost and selective ammonia sensor working at high temperatures.

One of the most promising solid-state ammonia sensors suitable for harsh environments is mixed-potential type sensors with yttria-stabilized zirconia (YSZ) electrolyte [2-4]. The main advantages of these mixed-potential type gas sensors that distinguish them from other types of sensors, are higher stability and reproducibility, wide flexibility for targeting gas species by changing the composition of the electrodes operating under open circuit or biased mode, and the ability to detect changes in gas content on timescales of milliseconds [5]. Indeed, these sensors have special features such as high-temperature operation, excellent sensing performance, and high chemical and mechanical stability [6]. They have also been studied extensively due to their fast response, high sensitivity, and long-term stable results $[3,4]$.

So far, numerous studies have been performed to find a sensitive and selective ammonia sensor at high temperatures. Different approaches have been suggested to achieve an effective ammonia sensor by modifying electrolyte $[7,8]$, reference electrode $[3,9]$ or sensing electrode [9-16].

Indeed, in these sensors, choosing a suitable material as a sensing electrode is very important for developing sensitive and selective sensors. A high electro-catalytic activity, as well as catalytic selectivity, are imperative for the sensing element of these sensors, especially in planar configuration. Among them, vanadium based sensing electrodes looks very promising. For example, Wang et al. in 2006 [9] published a patent (from Delphi Inc.) in which they reported the results of nineteen different sensors with various vanadium based electrode materials. After testing different materials, they found $\mathrm{BiVO}_{4}$ as the most appropriate material for a selective ammonia sensor. Liu et al. in 2015 [16] developed a sensor using stabilized zirconia (YSZ) and sensing electrode (SE) of $\mathrm{Ni}_{3} \mathrm{~V}_{2} \mathrm{O}_{8}$ oxide. They showed that $\mathrm{Ni}_{3} \mathrm{~V}_{2} \mathrm{O}_{8}$ calcined at $1000{ }^{\circ} \mathrm{C}$ exhibited the largest sensitivity in an $\mathrm{NH}_{3}$ concentration range of $50-500 \mathrm{ppm}$ at $650{ }^{\circ} \mathrm{C}$. Wang et al. in 2016 [12] used $\mathrm{V}_{2} \mathrm{O}_{5}-\mathrm{WO}_{3}-\mathrm{TiO}_{2}$ (VWT) material to get an ammonia selective electrode. The sensing electrode was consisted of Pt covered with a porous VWT catalyst layer. 
In addition, vanadium dioxide $\left(\mathrm{V}_{2} \mathrm{O}_{5}\right)$ is also well-known as sensitive material to ammonia even at ppb levels $[12,17]$.

Taking into account our past results with Pt/YSZ/Au configuration for NOx sensors [18-20] and literature results dealing with $\mathrm{NH}_{3}$ sensors, especially based on $\mathrm{V}_{2} \mathrm{O}_{5}$ material, the objective of the present study is to developed sensitive and selective $\mathrm{NH}_{3}$ sensors, using $\mathrm{Au}-\mathrm{V}_{2} \mathrm{O}_{5}$ material as sensing electrode. For this, three mass percentages of $\mathrm{V}_{2} \mathrm{O}_{5}$ to $\mathrm{Au}(15,30$, and 50 wt.\%) are used. The results of these sensors to different interfering gases such as $\mathrm{CO}, \mathrm{NO}_{2}$, $\mathrm{NO}, \mathrm{H}_{2}$, and hydrocarbons are studied. In addition, sensor responses to different $\mathrm{O}_{2}$ and $\mathrm{NH}_{3}$ concentrations are investigated. Finally, mixed potential theory based on Butler-Volmer equation is used to model the obtained results.

\section{Experimental}

The fabrication of sensors was performed by a screen-printing method using R-23 Meteor 23 semi-automatic screen-printer. Commercially available Pt (ESL 5545) and Au (ESL 8880-H) inks were used while YSZ (TZ-8YS) and $\mathrm{V}_{2} \mathrm{O}_{5}$ (Sigma-Aldrich) homemade inks were elaborated using commercial powders. For preparing homemade inks, a binder (ESL V400A) and an organic solvent (ESL 404) were added to commercial powders. For $\mathrm{Au}-\mathrm{V}_{2} \mathrm{O}_{5}$ sensing electrodes, a mixture of $\mathrm{Au}$ commercial ink and $\mathrm{V}_{2} \mathrm{O}_{5}$ home-made ink was prepared with 15, 30 and 50 wt.\% of $\mathrm{V}_{2} \mathrm{O}_{5}$.

The sensors were developed in planar configuration on alumina substrates as supports. A YSZ electrolyte layer was first deposited on the substrate following by 2 hours sintering at $1380{ }^{\circ} \mathrm{C}$. The reference (RE: Pt) and sensing electrodes ( $\mathrm{SE}: \mathrm{Au}$ or $\left.\mathrm{Au}-\mathrm{V}_{2} \mathrm{O}_{5}\right)$ were then printed on the YSZ layer. The sintering temperatures for $\mathrm{Pt}$ reference electrode and $\mathrm{Au}-\mathrm{V}_{2} \mathrm{O}_{5}$ sensing electrode were $850{ }^{\circ} \mathrm{C}$ and $600{ }^{\circ} \mathrm{C}$ during 1 hour respectively. In order to provide the high working temperature of sensors, a heating element in the form of a platinum resistor was printed on the opposite side of the alumina substrate, facing the YSZ electrolyte. Fig. 1 shows the sensing and heating sides of a final sensor with different elements. Although Pt electrode is not in a reference chamber as the sensor is in planar configuration, we keep the name "reference electrode (RE)" as it has been shown that Pt behaves like a reference in such single chamber, in regards of other oxide based electrodes designed as sensing electrodes (SE) [21]. 
To identify the sensors with different sensing elements, the mass percentage of $\mathrm{V}_{2} \mathrm{O}_{5}$ is indicated in their name. Sensors with 15 wt. $\% \mathrm{~V}_{2} \mathrm{O}_{5}$ are named as $\mathrm{Au}-15 \% \mathrm{~V}_{2} \mathrm{O}_{5}$, with the same labeling for 30 wt. $\% \mathrm{~V}_{2} \mathrm{O}_{5}\left(\mathrm{Au}-30 \% \mathrm{~V}_{2} \mathrm{O}_{5}\right)$, and $50 \mathrm{wt} . \% \mathrm{~V}_{2} \mathrm{O}_{5}\left(\mathrm{Au}-50 \% \mathrm{~V}_{2} \mathrm{O}_{5}\right)$.

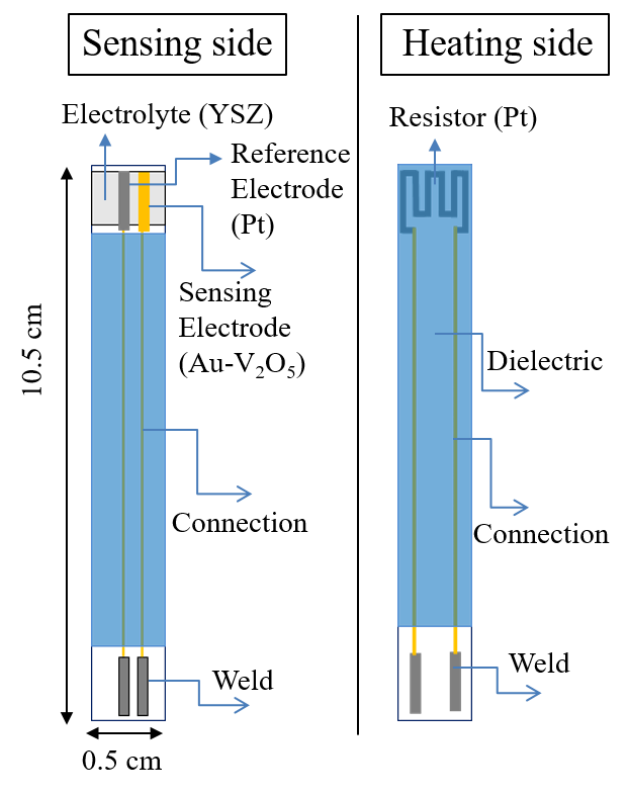

Fig. 1 Scheme of fabricated sensor by screen-printing technology.

A test bench was used to study the responses of two sensors working simultaneously in separate cells, thus allowing to check the signal reproducibility. A schematic of the experimental test bench is shown in Fig. 2. The various studied gases were conditioned in separated cylinders and their flow rates were monitored by mass flow regulators. The total flow rate was fixed at $60 \mathrm{l} / \mathrm{h}$, corresponding to $30 \mathrm{l} / \mathrm{h}$ per cell. An humidifier allowed to generate and control water vapor in the gas flow. Gases first arrived in a mixing chamber before being sent to the two cells, which each contained one sensor. An FTIR gas analyzer (Gasmet DX 4015) was used to analyze the gas leaving sensor cells.

Sensors responses to different gases such as $\mathrm{CO}, \mathrm{NH}_{3}, \mathrm{NO}_{2}, \mathrm{NO}, \mathrm{H}_{2}$ and $\mathrm{C}_{\mathrm{x}} \mathrm{H}_{\mathrm{y}}$ were studied. The hydrocarbon gas $\left(\mathrm{C}_{\mathrm{x}} \mathrm{H}_{\mathrm{y}}\right)$ used in this study was composed of $56 \mathrm{~mol} . \%$ propene $\left(\mathrm{C}_{3} \mathrm{H}_{6}\right), 28$ mol.\% n-butane $\left(\mathrm{n}-\mathrm{C}_{4} \mathrm{H}_{10}\right)$ and $16 \mathrm{~mol} . \%$ methane $\left(\mathrm{CH}_{4}\right)$. The base gas was composed of 2, 5, 12 or 16.4 mol.\% $\mathrm{O}_{2}$ balanced with $\mathrm{N}_{2}$ with 1.5 vol.\% absolute humidity. The sensor signal $\left(\Delta V_{R E}^{0}\right)$ is the potential difference between the reference electrode and the sensing electrode $\left(\Delta V_{R E}^{0}=\mathrm{V}_{\mathrm{RE}}-\mathrm{V}_{\mathrm{SE}}\right)$. Then, the response to a target gas is defined as the difference of the sensor signal in presence of this gas minus the sensor signal under base gas with the same oxygen content (response $=\Delta V_{R E, g a s}^{0}-\Delta V_{R E, \text { basegas }}^{0}$ ). 


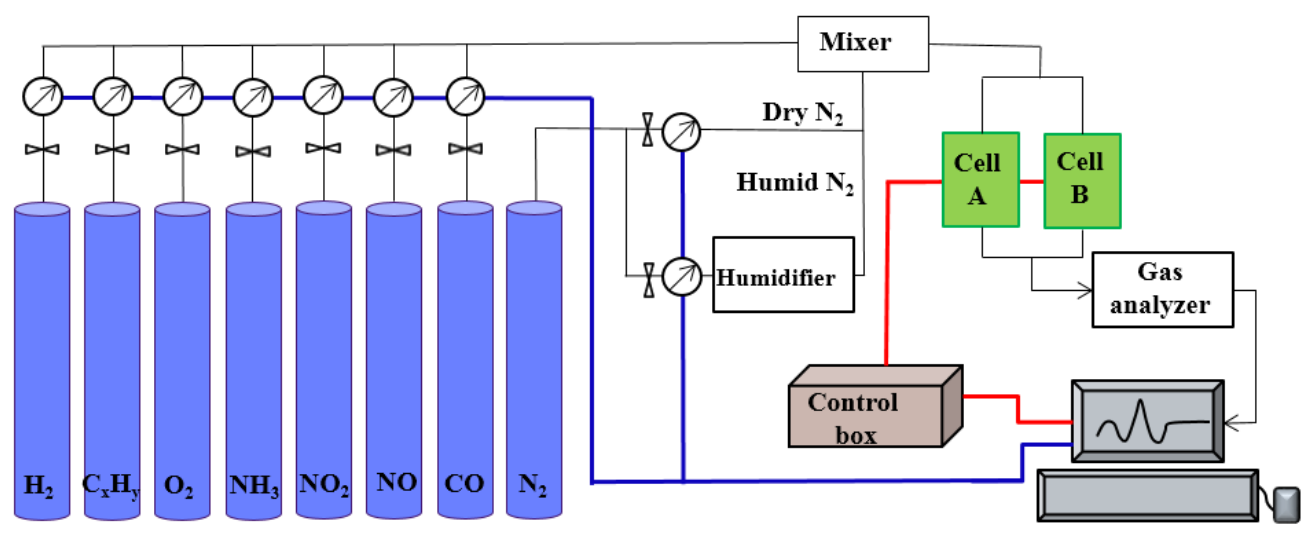

Fig. 2 Schematic of experimental test bench.

\section{Results and discussions}

\subsection{Comparison between $\mathrm{Au}$ and $\mathrm{Au}-15 \% \mathrm{~V}_{2} \mathrm{O}_{5}$ sensing electrodes: influence of operating temperature}

Sensors with $\mathrm{Au}$ and $\mathrm{Au}-15 \% \mathrm{~V}_{2} \mathrm{O}_{5}$ sensing electrodes were exposed successively to $100 \mathrm{ppm}$ $\mathrm{CO}, \mathrm{NO}_{2}, \mathrm{NO}$, and $20 \mathrm{ppm}$ of $\mathrm{NH}_{3}$ at different working temperatures in the range $450-600^{\circ} \mathrm{C}$. The base gas in this experiment was composed of 12 mol.\% $\mathrm{O}_{2}$ balanced with $\mathrm{N}_{2}$ and $1.5 \mathrm{vol} . \%$ absolute humidity. First, to emphasize the interest of $\mathrm{V}_{2} \mathrm{O}_{5}$ based electrodes, responses of $\mathrm{Pt} / \mathrm{YSZ} / \mathrm{Au}-15 \% \mathrm{~V}_{2} \mathrm{O}_{5}$ sensors were compared to the ones of a $\mathrm{Pt} / \mathrm{YSZ} / \mathrm{Au}$ sensors already reported for NOx detection in our previous studies [19- 20]. With our definition of sensor signal $\left(\Delta V_{R E}^{0}=\mathrm{V}_{\mathrm{RE}}-\mathrm{V}_{\mathrm{SE}}\right)$ and response, a typical behavior of such Pt/YSZ/Au sensors is a positive response to reducing gases $\left(\mathrm{CO}, \mathrm{NO}\right.$ and $\left.\mathrm{NH}_{3}\right)$, and a negative one to oxidants ones like $\mathrm{NO}_{2}$. Figure 3 showing the signal of an $\mathrm{Au}-15 \% \mathrm{~V}_{2} \mathrm{O}_{5}$ based sensor confirms that the substitution of $\mathrm{Au}$ by $\mathrm{Au}-15 \% \mathrm{~V}_{2} \mathrm{O}_{5}$ as sensing electrode does not modify qualitatively the behavior. 


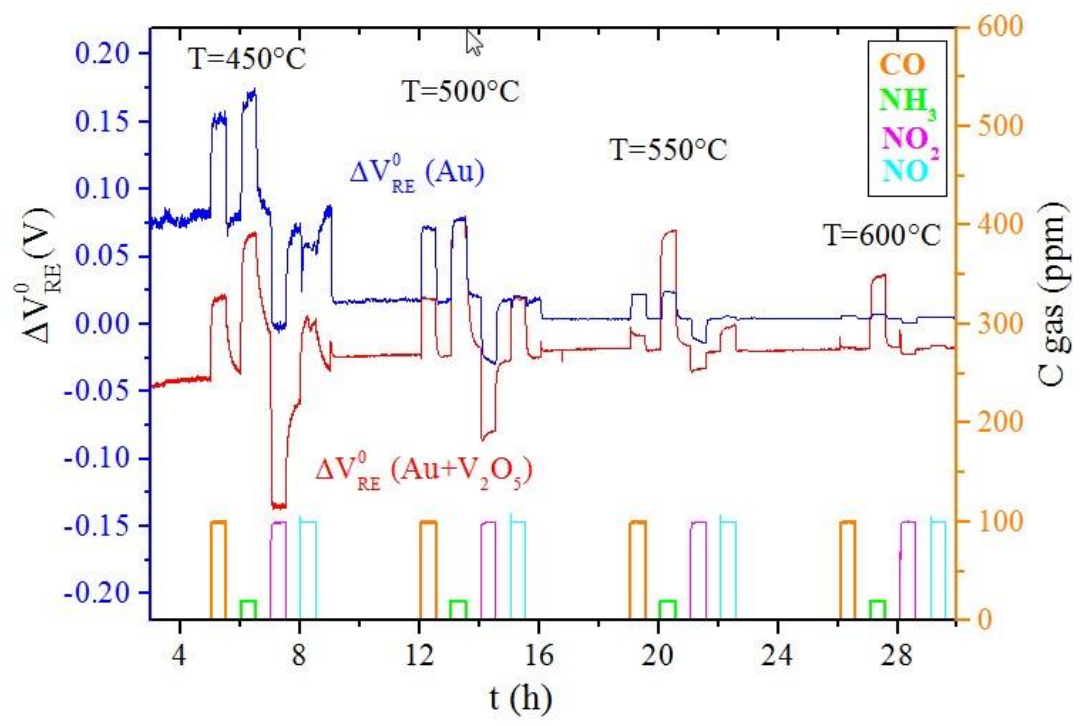

Fig. 3 Signals of sensors with $\mathrm{Au}$ (in blue) and $\mathrm{Au}-15 \% \mathrm{~V}_{2} \mathrm{O}_{5}$ (in red) sensing electrodes for $100 \mathrm{ppm} \mathrm{CO}, \mathrm{NO}_{2}, \mathrm{NO}$ and $20 \mathrm{ppm}$ of $\mathrm{NH}_{3}$ at $450,500,550$, and $600{ }^{\circ} \mathrm{C}$, in the base gas with $12 \mathrm{~mol} . \% \mathrm{O}_{2}$.

By comparing quantitatively responses of both types of sensors (Table 1), it can be observed that responses related to Au electrode decrease considerably by increasing temperature from $450^{\circ} \mathrm{C}$ (absolute value in the range $14-87 \mathrm{mV}$ ) up to $600^{\circ} \mathrm{C}$ (absolute value lower than $3 \mathrm{mV}$ ). Regarding $\mathrm{Au}-15 \% \mathrm{~V}_{2} \mathrm{O}_{5}$ device, responses to $\mathrm{CO}, \mathrm{NO}_{2}$ and $\mathrm{NO}$ also decrease in a similar way when the temperature is increased. However, $\mathrm{NH}_{3}$ response is quite less affected: its response decreases from $91 \mathrm{mV}\left(450^{\circ} \mathrm{C}\right)$ down to $66 \mathrm{mV}$ at $600^{\circ} \mathrm{C}$, which remains significant in regards of the one of other gases. Hence, a selective ammonia sensor is obtained when increasing the temperature as the cross-sensitivity to other interfering gases, such as $\mathrm{CO}, \mathrm{NO}_{2}$ and $\mathrm{NO}$, is strongly reduced at $600^{\circ} \mathrm{C}$, as seen in figure 3 . 
Table 1 Comparison of $\mathrm{Au}$ and $\mathrm{Au}-15 \% \mathrm{~V}_{2} \mathrm{O}_{5}$ electrodes in sensor responses to pulses of $\mathrm{CO}$ $(100 \mathrm{ppm}), \mathrm{NH}_{3}(20 \mathrm{ppm}), \mathrm{NO}_{2}(100 \mathrm{ppm})$ and $\mathrm{NO}(100 \mathrm{ppm})$ in base gas at different temperatures.

\begin{tabular}{|c|c|c|c|c|c|}
\hline $\begin{array}{l}\text { Temperature } \\
\left({ }^{\circ} \mathrm{C}\right)\end{array}$ & Sensor & $\begin{array}{l}\mathrm{CO} \\
\text { response } \\
(\mathrm{mV})\end{array}$ & $\begin{array}{l}\mathrm{NH}_{3} \\
\text { response } \\
(\mathrm{mV})\end{array}$ & $\begin{array}{l}\mathrm{NO}_{2} \\
\text { response } \\
(\mathrm{mV})\end{array}$ & $\begin{array}{l}\mathrm{NO} \\
\text { response } \\
(\mathrm{mV})\end{array}$ \\
\hline 450 & $\begin{array}{l}\mathrm{Au} \\
\mathrm{Au}-15 \% \mathrm{~V}_{2} \mathrm{O}_{5}\end{array}$ & $\begin{array}{l}72 \\
51\end{array}$ & $\begin{array}{l}87 \\
91\end{array}$ & $\begin{array}{l}-82 \\
-65\end{array}$ & $\begin{array}{l}14 \\
52\end{array}$ \\
\hline 500 & $\begin{array}{l}\mathrm{Au} \\
\mathrm{Au}-15 \% \mathrm{~V}_{2} \mathrm{O}_{5}\end{array}$ & $\begin{array}{l}53 \\
25\end{array}$ & $\begin{array}{l}58 \\
91\end{array}$ & $\begin{array}{l}-38 \\
-27\end{array}$ & $\begin{array}{l}7 \\
29\end{array}$ \\
\hline 550 & $\begin{array}{l}\mathrm{Au} \\
\mathrm{Au}-15 \% \mathrm{~V}_{2} \mathrm{O}_{5}\end{array}$ & $\begin{array}{l}18 \\
19\end{array}$ & $\begin{array}{l}20 \\
84\end{array}$ & $\begin{array}{l}-15 \\
-32\end{array}$ & $\begin{array}{l}2 \\
21\end{array}$ \\
\hline 600 & $\begin{array}{l}\mathrm{Au} \\
\mathrm{Au}-15 \% \mathrm{~V}_{2} \mathrm{O}_{5}\end{array}$ & $\begin{array}{l}2 \\
2\end{array}$ & $\begin{array}{l}3 \\
66\end{array}$ & $\begin{array}{l}-3 \\
-5\end{array}$ & $\begin{array}{l}0 \\
3\end{array}$ \\
\hline
\end{tabular}

\subsection{Effect of $\mathrm{V}_{2} \mathrm{O}_{5}$ content in $\mathrm{Au}-\mathrm{V}_{2} \mathrm{O}_{5}$ sensing electrode}

In addition to 15 wt. $\%$ of $\mathrm{V}_{2} \mathrm{O}_{5}$, two other mass percentages of $\mathrm{V}_{2} \mathrm{O}_{5}$ were tested in the sensing electrode (30 wt. $\%$ and 50 wt. $\%$ of $\left.\mathrm{V}_{2} \mathrm{O}_{5}\right)$. The different sensors $\left(\mathrm{Au}-15 \% \mathrm{~V}_{2} \mathrm{O}_{5}, \mathrm{Au}-30 \% \mathrm{~V}_{2} \mathrm{O}_{5}\right.$ and $\mathrm{Au}-50 \% \mathrm{~V}_{2} \mathrm{O}_{5}$ ) were exposed to $100 \mathrm{ppm} \mathrm{CO}, \mathrm{NO}_{2}, \mathrm{NO}$, and $20 \mathrm{ppm}$ of $\mathrm{NH}_{3}$ at four temperatures of $450,500,550$ and $600{ }^{\circ} \mathrm{C}$. The base gas was again composed of $12 \mathrm{~mol} \% \mathrm{O}_{2}$ balanced with $\mathrm{N}_{2}$ and 1.5 vol.\% absolute humidity. Gas responses of these sensors (absolute value for $\mathrm{NO}_{2}$ ) were compared with each other at the four temperatures in Fig. 4. The results show that the gas responses for all sensors decrease by increasing the temperature (as observed before for $\mathrm{Au}-15 \% \mathrm{~V}_{2} \mathrm{O}_{5}$ ). Sensors respond significantly to all gases at $450{ }^{\circ} \mathrm{C}$ and $500{ }^{\circ} \mathrm{C}$. By increasing the temperature up to $550{ }^{\circ} \mathrm{C}$, the selectivity of $30 \% \mathrm{~V}_{2} \mathrm{O}_{5}$ and $50 \% \mathrm{~V}_{2} \mathrm{O}_{5}$ sensors for $\mathrm{NH}_{3}$ detection is largely increased, while $15 \% \mathrm{~V}_{2} \mathrm{O}_{5}$ sensors still show responses to $\mathrm{CO}, \mathrm{NO}_{2}$ and NO at this temperature. Finally, all sensors show selective responses toward ammonia at $600{ }^{\circ} \mathrm{C}$.

One of the main challenges of these sensors is long-term stability. Since the melting point of $\mathrm{V}_{2} \mathrm{O}_{5}$ is $680{ }^{\circ} \mathrm{C}$ [22] $\left(650^{\circ} \mathrm{C}\right.$ in some studies [23]), there is a high possibility that an operating 
temperature of $600^{\circ} \mathrm{C}$ for a long period could cause damage of $\mathrm{Au}-\mathrm{V}_{2} \mathrm{O}_{5}$ sensing electrode. Indeed, test conducted at $600^{\circ} \mathrm{C}$ during 48 hours have confirmed a strong degradation of the sensing electrode, contrary to observations made after similar experiments at $550^{\circ} \mathrm{C}$ showing neither electrode degradation, nor sensor signal alteration. Therefore, a temperature of $550^{\circ} \mathrm{C}$ is a good compromise between long-term stability and $\mathrm{NH}_{3}$ selectivity.

At $550^{\circ} \mathrm{C}$, since $50 \% \mathrm{~V}_{2} \mathrm{O}_{5}$ based sensors show a slightly improved selectivity compared to $30 \% \mathrm{~V}_{2} \mathrm{O}_{5}$ ones, especially regarding $\mathrm{CO}$ interference, $\mathrm{Au}-50 \% \mathrm{~V}_{2} \mathrm{O}_{5}$ sensor was selected for the rest of this study.
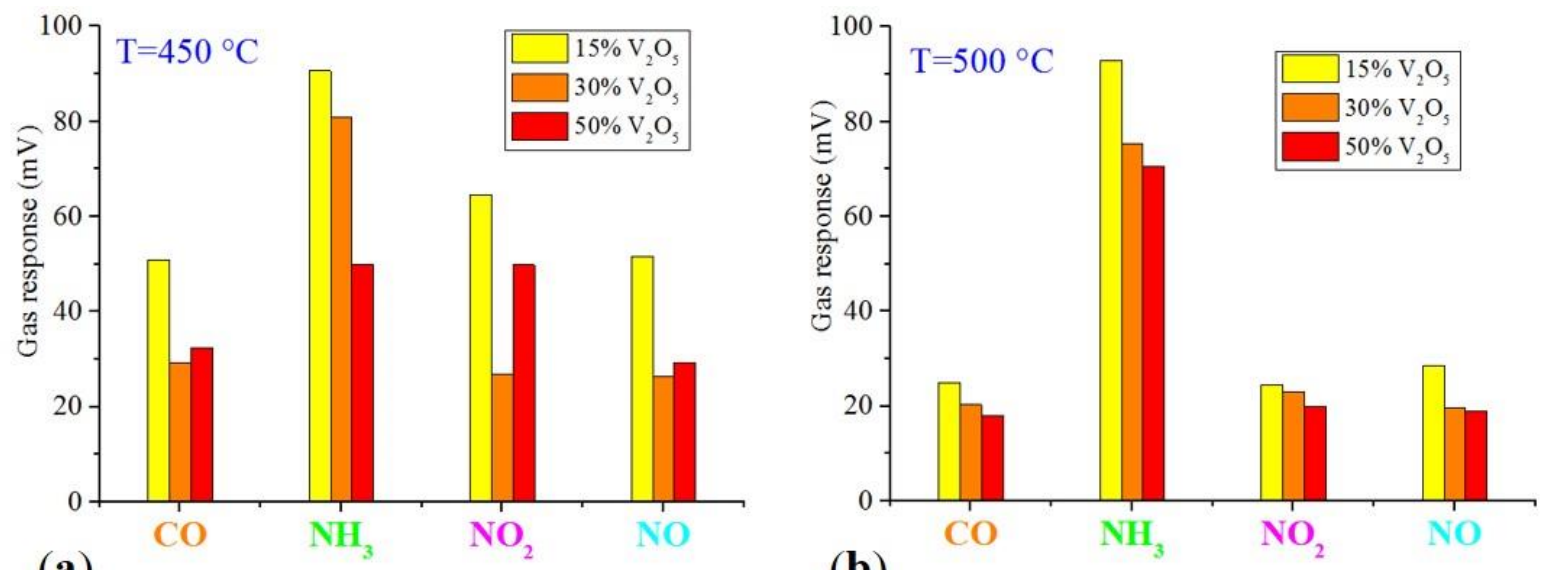

(a)

(b)
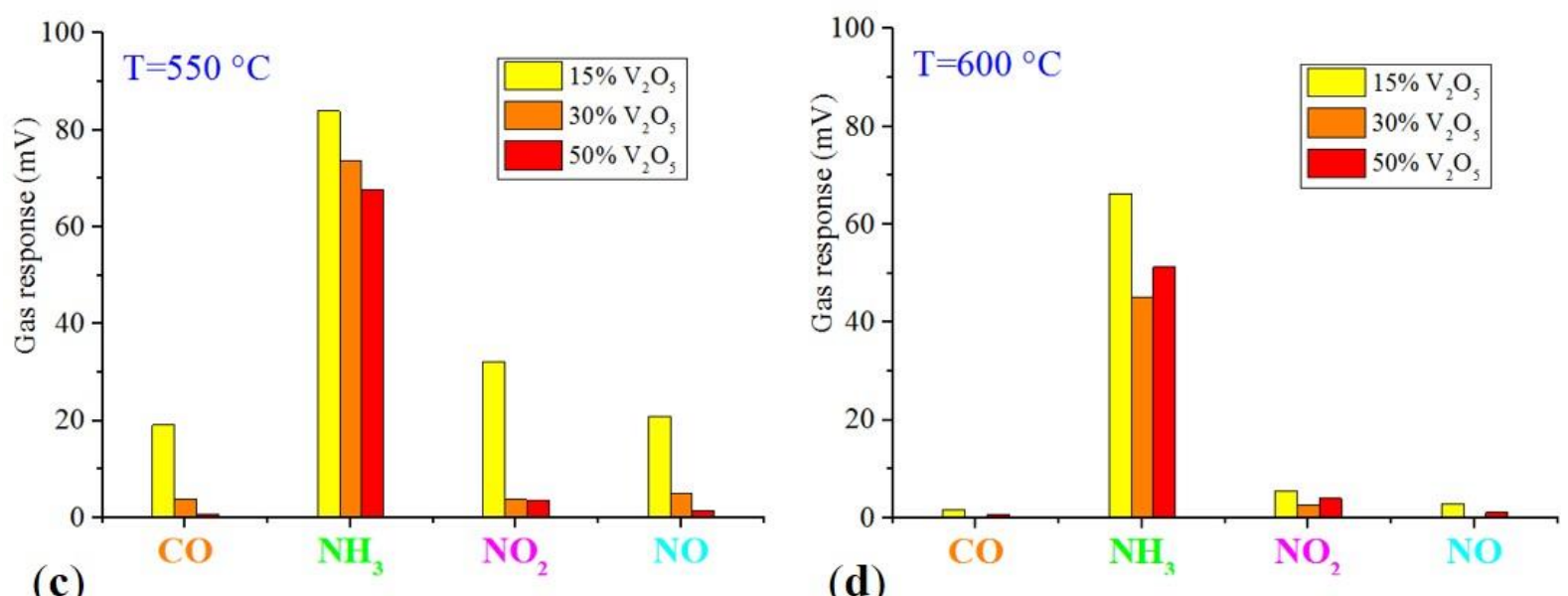

Fig. 4 Gas sensor responses (absolute value for $\mathrm{NO}_{2}$ ) of $\mathrm{Au}-\mathrm{V}_{2} \mathrm{O}_{5}$ based sensors with three mass percentages of $15 \%, 30 \%$ and $50 \%$ of $\mathrm{V}_{2} \mathrm{O}_{5}$ at (a) $450{ }^{\circ} \mathrm{C}$, (b) $500^{\circ} \mathrm{C}$, (c) $550{ }^{\circ} \mathrm{C}$, and (d) $600^{\circ} \mathrm{C}$. 


\subsection{Morphology of $\mathrm{Au}-50 \% \mathrm{~V}_{2} \mathrm{O}_{5}$ electrode on YSZ electrolyte}

The morphology of the selected $\mathrm{Au}-50 \% \mathrm{~V}_{2} \mathrm{O}_{5}$ sensing electrode was characterized by Scanning Electron Microscopy (SEM, ZEISS SUP RA-55 VP). Cross-section micrograph is shown in Fig. 5. It can be seen that Au particles (white color) are well dispersed in the whole porous sensing electrode. Although the mass percentage of $\mathrm{V}_{2} \mathrm{O}_{5}$ and $\mathrm{Au}$ is 50-50 in this electrode, $\mathrm{Au}$ particles quantity seems to be lower than that of $\mathrm{V}_{2} \mathrm{O}_{5}$. In fact, $50 \mathrm{wt} . \%$ of $\mathrm{V}_{2} \mathrm{O}_{5}$ corresponds to 85 vol.\% $\mathrm{V}_{2} \mathrm{O}_{5}$, due to the high density of gold compared to $\mathrm{V}_{2} \mathrm{O}_{5}\left(19.32{\mathrm{~g} . \mathrm{cm}^{-3}}\right.$ for $\mathrm{Au}$ compared to 3.36 g.cm $\mathrm{cm}^{-3}$ for $\mathrm{V}_{2} \mathrm{O}_{5}$ ).

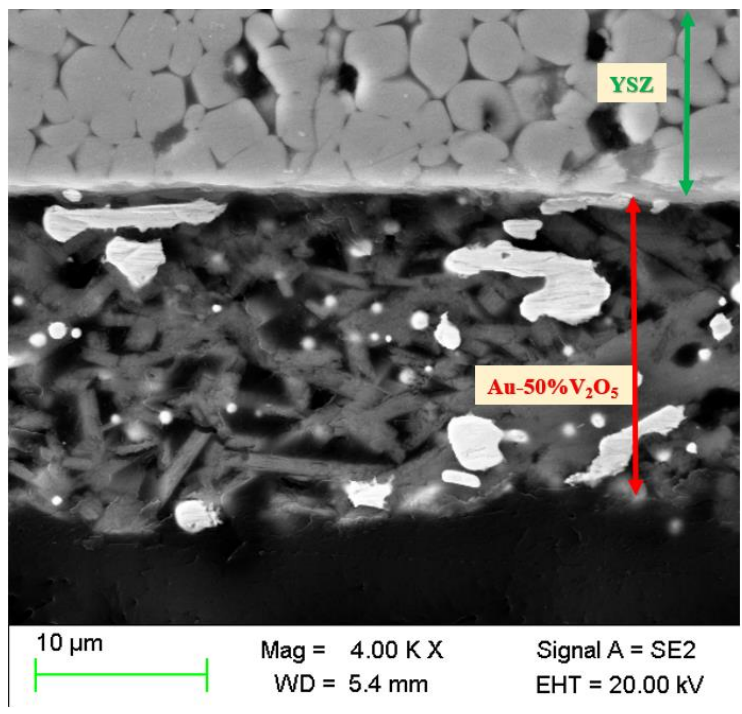

Fig. 5 Cross-section SEM micrograph of Au-50\% $\mathrm{V}_{2} \mathrm{O}_{5}$ electrode on YSZ electrolyte.

\subsection{Interference of $\mathrm{H}_{2}$ and $\mathrm{C}_{\mathrm{x}} \mathrm{H}_{\mathrm{y}}$ gases}

In prior tests, four gases $\mathrm{CO}, \mathrm{NH}_{3}, \mathrm{NO}_{2}$, and $\mathrm{NO}$ were tested to study the selectivity of the sensors. However, the sensor may be affected by other interfering gases. Hydrocarbons (HC) are among the most important species that may cause interference for $\mathrm{NH}_{3}$ sensors in car exhaust. Apart from hydrocarbons, almost all diesel-type vehicles emit marginal amounts of hydrogen (around $0.1 \mathrm{mg} / \mathrm{km}$ ). In some studies, hydrogen is reported as an interfering gas to the results of ammonia sensors [8]. Therefore, cross-sensitivity with these gases is also an important issue. To ensure the selectivity, $\mathrm{Au}-50 \% \mathrm{~V}_{2} \mathrm{O}_{5}$ sensors were tested with $100 \mathrm{ppm}$ hydrocarbon (56 mol.\% $\mathrm{C}_{3} \mathrm{H}_{6}, 28 \mathrm{~mol} . \% \mathrm{n}-\mathrm{C}_{4} \mathrm{H}_{10}, 16 \mathrm{~mol} . \% \mathrm{CH}_{4}$ ) and $20 \mathrm{ppm}$ of $\mathrm{H}_{2}$ at $550{ }^{\circ} \mathrm{C}$. 
The base gas in this experiment was also composed of 12 mol.\% $\mathrm{O}_{2}$ balanced with $\mathrm{N}_{2}$ and 1.5 vol.\% absolute humidity.

Fig 6. shows the response of a $\mathrm{Au}-50 \% \mathrm{~V}_{2} \mathrm{O}_{5}$ sensor to $100 \mathrm{ppm}$ of $\mathrm{CO}, 20 \mathrm{ppm}$ of $\mathrm{NH}_{3}, 100 \mathrm{ppm}$ of $\mathrm{NO}, 100 \mathrm{ppm}$ of $\mathrm{NO}_{2}, 100 \mathrm{ppm}$ of $\mathrm{C}_{\mathrm{x}} \mathrm{Hy}$ (2 times) and $20 \mathrm{ppm}$ of $\mathrm{H}_{2}$ (4 times). The results in Fig. 6 clearly show that sensors display no responses to $\mathrm{CO}, \mathrm{NO}$ and $\mathrm{NO}_{2}$ as previously seen and neither to hydrocarbons nor to hydrogen at $550{ }^{\circ} \mathrm{C}$.

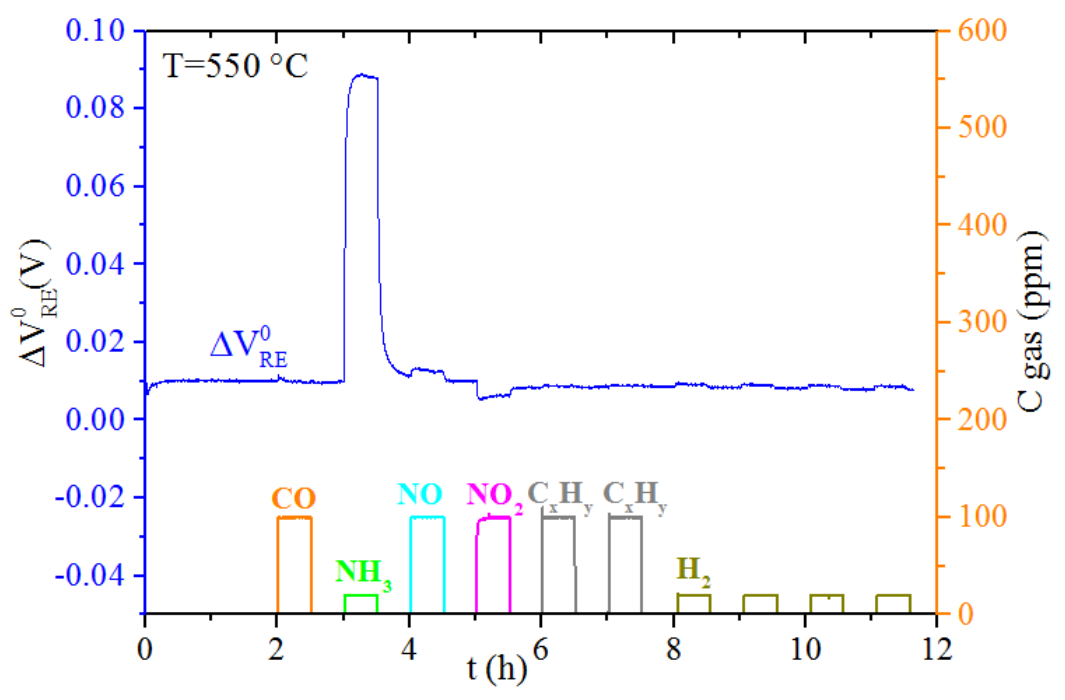

Fig. $6 \mathrm{Au}-50 \% \mathrm{~V}_{2} \mathrm{O}_{5}$ sensor signal for $100 \mathrm{ppm}$ of $\mathrm{CO}, 20 \mathrm{ppm}$ of $\mathrm{NH}_{3}, 100 \mathrm{ppm}$ of $\mathrm{NO}, 100$ ppm of $\mathrm{NO}_{2}, 100 \mathrm{ppm}$ of $\mathrm{C}_{\mathrm{x}} \mathrm{H}_{\mathrm{y}}$ (2 times), and $20 \mathrm{ppm}$ of $\mathrm{H}_{2}$ (4 times) at $550{ }^{\circ} \mathrm{C}$.

\section{5 $\mathrm{Au}-50 \% \mathrm{~V}_{2} \mathrm{O}_{5}$ sensors responses in gas mixtures}

Moreover, in previous tests, the sensing performances were studied with individual gases. However, in a real environment of gas exhaust, the pollutant gases exist altogether, which might disturb the responses of sensors to each gas. For this reason, sensors responses in gas mixtures were studied. To understand if the sensors responses were coherent with the gas existing in the mixture, a gas analyzer instrument (Gasmet DX 4015 FTIR analyzer) was used to monitor the gas composition at the exit of sensors cells. The sensor responses in different

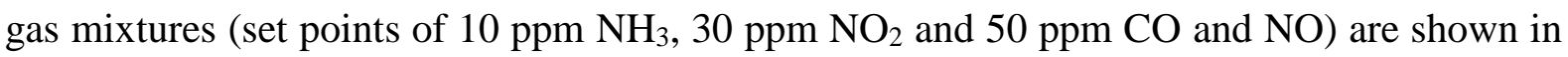
Fig. 7 (with 12 mol.\% $\mathrm{O}_{2}$ balanced with $\mathrm{N}_{2}$ and 1.5 vol.\% absolute humidity as base gas). Fig. 7 also shows results of gas analyses and gas concentration set point. 


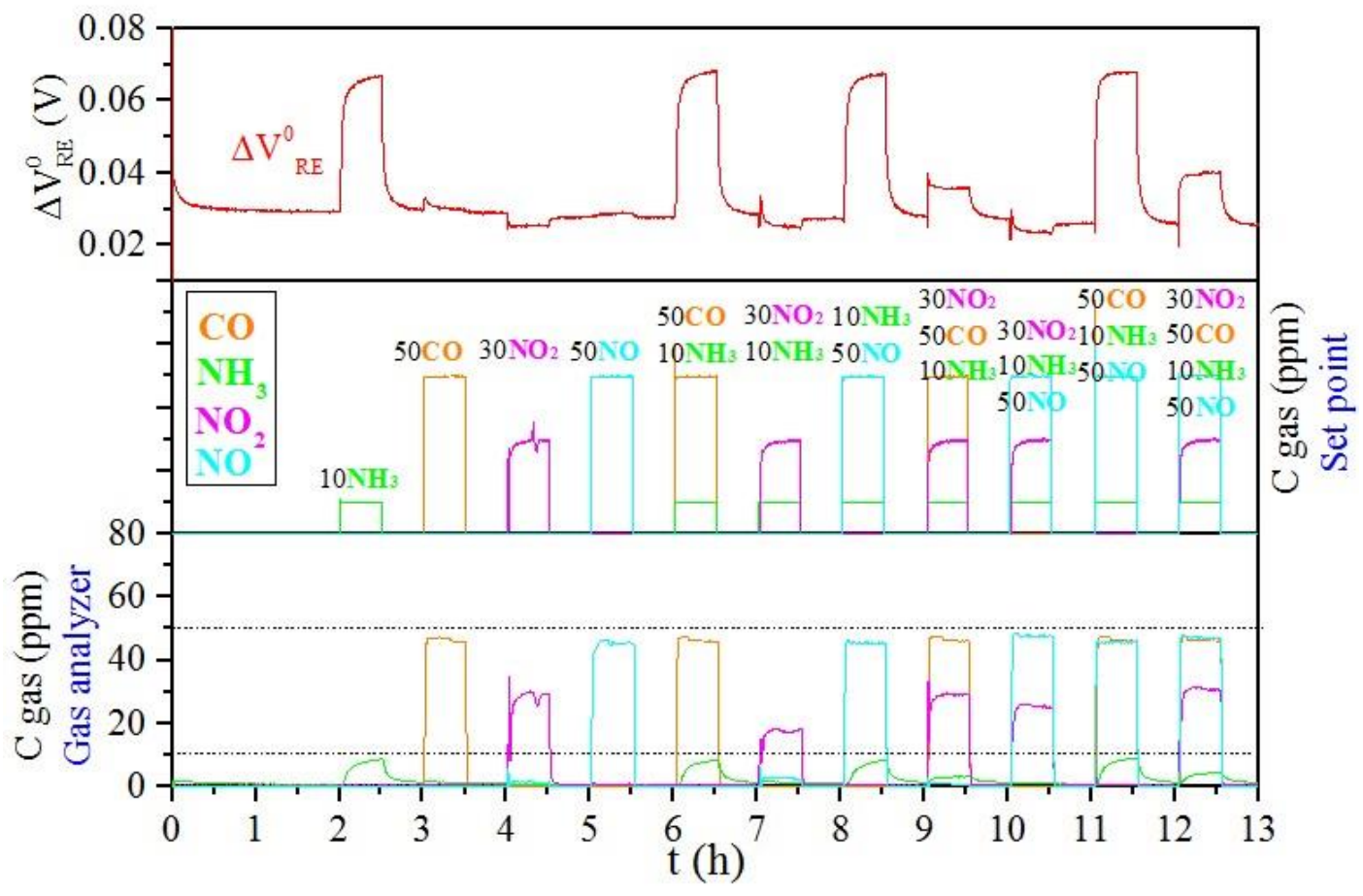

Fig. $7 \mathrm{Au}-50 \% \mathrm{~V}_{2} \mathrm{O}_{5}$ sensor signal in a single gas or gas mixtures of $\mathrm{CO}, \mathrm{NH}_{3}, \mathrm{NO}_{2}$, and $\mathrm{NO}$ at $550{ }^{\circ} \mathrm{C}$ with gas analysis at the cell exit.

For single gas, as expected, the sensor has high responses to $10 \mathrm{ppm}$ of $\mathrm{NH}_{3}(38 \mathrm{mV})$, no responses to $50 \mathrm{ppm} \mathrm{CO}$ and $\mathrm{NO}$, and negligible negative responses to $30 \mathrm{ppm} \mathrm{NO}_{2}$ at $550{ }^{\circ} \mathrm{C}$. In binary gas mixtures, when injecting $\mathrm{NH}_{3}$ in the presence of $\mathrm{NO}_{2}$, it can be seen through gas analyzer that there is no more $\mathrm{NH}_{3}$ gas at the exit. Furthermore, $\mathrm{NO}_{2}$ concentration is slightly decreased (around $20 \mathrm{ppm}$ ) compared to the single gas measurement (around $30 \mathrm{ppm}$ ). In fact, this phenomenon is also observed when there is no sensor in the cell. This means that a reaction in gas phase occurs between $\mathrm{NH}_{3}$ and $\mathrm{NO}_{2}$, and $\mathrm{NH}_{3}$ is completely consumed by $\mathrm{NO}_{2}$ (according to reaction (1)) in our experimental conditions. Hence, the absence of sensor response to $\mathrm{NH}_{3}$ when mixed with $\mathrm{NO}_{2}$ is simply explained by the fact there is no more $\mathrm{NH}_{3}$ in the gas phase, and it is also coherent with lower $\mathrm{NO}_{2}$ concentration at the cell exit. Looking at the sensor response in other binary gas mixtures, $\mathrm{CO}$ and $\mathrm{NO}$ gases do not affect significantly sensor response to $\mathrm{NH}_{3}$.

$$
2 \mathrm{NO}_{2}+\mathrm{O}_{2}+4 \mathrm{NH}_{3} \rightarrow 3 \mathrm{~N}_{2}+6 \mathrm{H}_{2} \mathrm{O}
$$

Considering the gas analyzer results in three-gas mixtures, the main results are similar to those observed in two gas mixtures. The sensor response to $\mathrm{NH}_{3}$ is coherent with gas analyzer results. If $\mathrm{NH}_{3}$ is consumed by $\mathrm{NO}_{2}$, the sensor logically does not show significant responses. It is also 
noticed that $\mathrm{CO}$ presence may limit $\mathrm{NO}_{2} / \mathrm{NH}_{3}$ reaction. Therefore, $\mathrm{NH}_{3}$ is detected in $\mathrm{NO}_{2} / \mathrm{NH}_{3}$ gas mixtures only in the presence of $\mathrm{CO}$. As a conclusion, the results show that the sensor responds to $\mathrm{NH}_{3}$ whenever it is present in the gas phase, and sensor responses to other gases are negligible.

\subsection{Sensitivity to $\mathrm{NH}_{3}$ with varying oxygen concentrations}

All previous tests were performed with a fixed oxygen content at $12 \mathrm{~mol} \%$. In real conditions, its content can vary suddenly in a great range. Hence, sensing performances were studied at $550{ }^{\circ} \mathrm{C}$ by stepwise change in the $\mathrm{NH}_{3}$ concentration from 2 to $40 \mathrm{ppm}(2,4,8,16,32$, and 40 $\mathrm{ppm})$ at four different concentrations of oxygen $(2 \%, 5 \%, 12 \%$, and $16.4 \mathrm{~mol} \%)$. The results are shown in Fig. 8. It can be seen that the sensor baseline (when there is no $\mathrm{NH}_{3}$ ), decreases with increasing $\mathrm{O}_{2}$ concentration. The results also indicate that the sensor has a high sensitivity to ammonia, even at low concentrations ( $2 \mathrm{ppm}$ ), but it is influenced by the oxygen concentration. This phenomenon indicates competitive adsorption between $\mathrm{NH}_{3}$ and $\mathrm{O}_{2}$ on the sensing electrode, which is modeled in the next part.

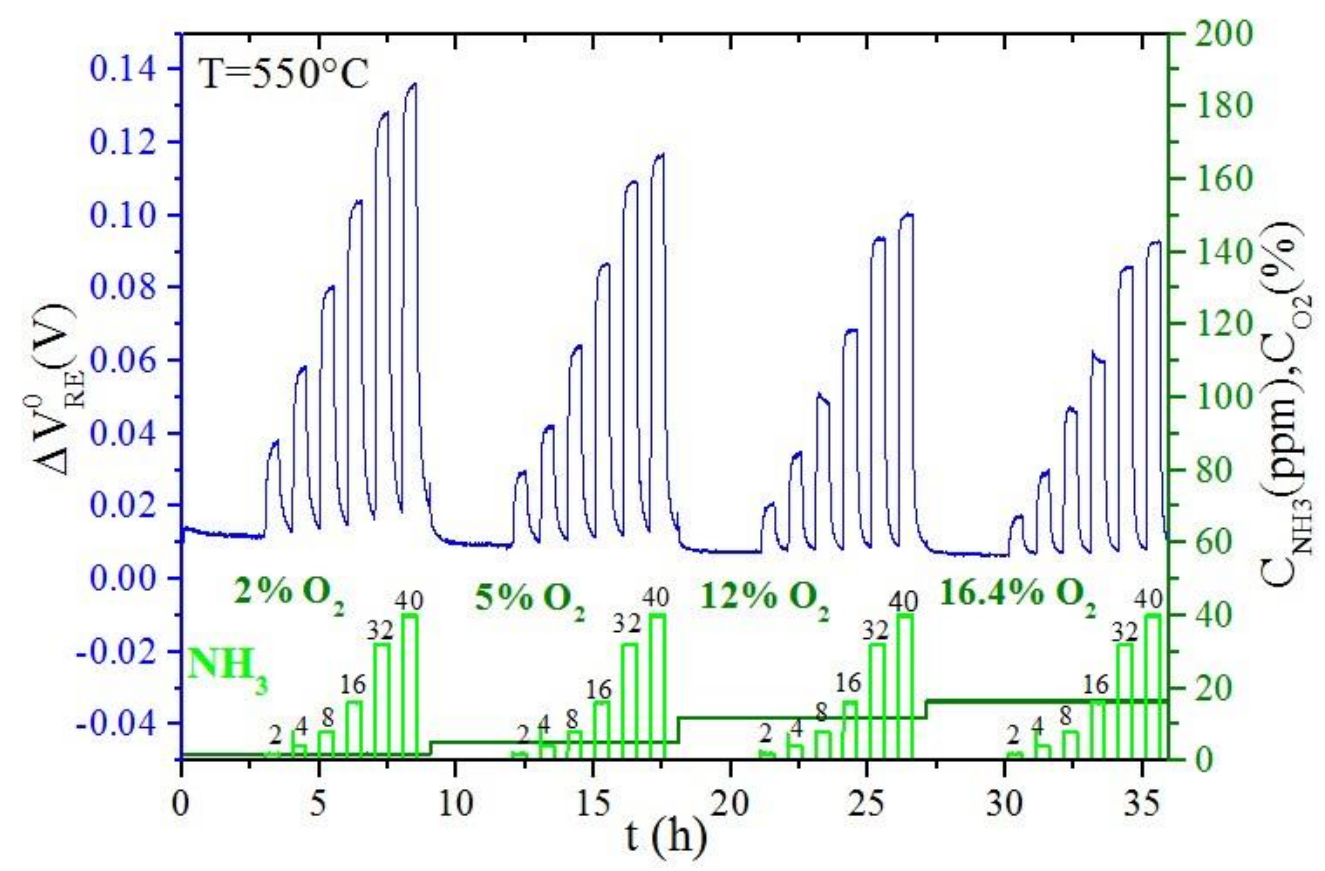

Fig. $8 \mathrm{Au}-50 \% \mathrm{~V}_{2} \mathrm{O}_{5}$ sensors signal for different concentrations of $\mathrm{NH}_{3}(2,4,8,16,32$, and 40 ppm) at four oxygen concentrations $(2,5,12$, and $16.4 \mathrm{~mol} . \%)$ at $550{ }^{\circ} \mathrm{C}$. 
Fig. 9 shows the variations of $\mathrm{NH}_{3}$ signals as a function of $\log \left(C_{N H 3}\right)$. It is seen that the signal changes linearly with the logarithm of $\mathrm{NH}_{3}$ concentrations in the examined range. This is in agreement with reported results on planar potentiometric sensor [4, 24] and mixed potential theory $[25,26]$. The slopes of the obtained lines indicate the sensitivity of the sensor to ammonia (defined with $\log \left(C_{N H 3}\right)$ ), which are respectively $75.9,69.2,62.4$, and 58.6 $\mathrm{mV} /$ decades for $2 \%, 5 \%, 12 \%$, and $16.4 \% \mathrm{O}_{2}$ concentrations. Therefore, $\mathrm{NH}_{3}$ sensitivity of the sensor decreases by increasing $\mathrm{O}_{2}$ concentration. These values are in the same range as $\mathrm{NH}_{3}$ potentiometric sensor reported in the literature [4, 24].

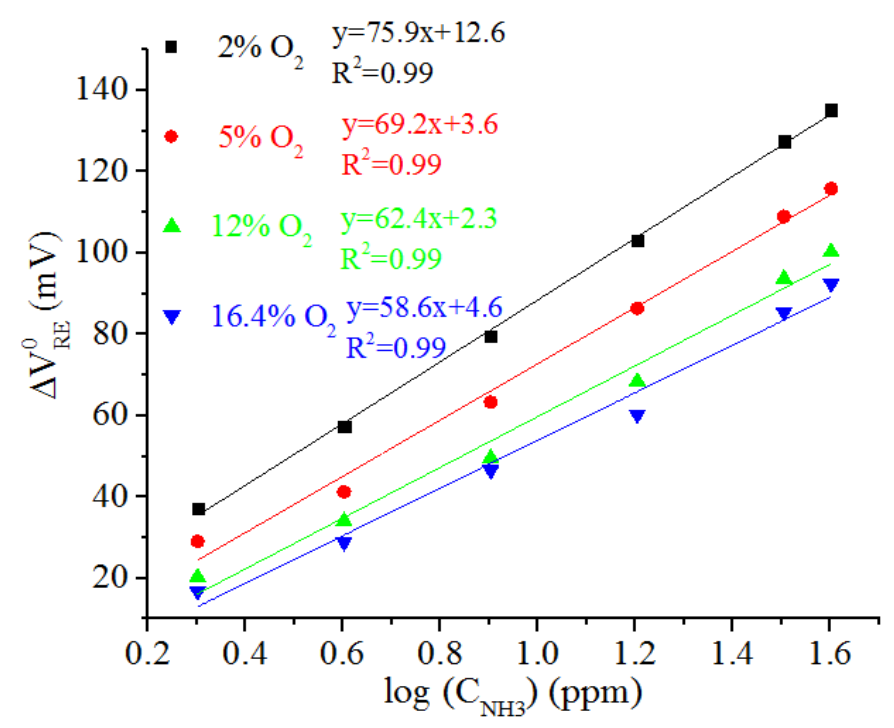

Fig. 9 Variations of $\mathrm{Au}-50 \% \mathrm{~V}_{2} \mathrm{O}_{5}$ sensor signals as a function of $\log \left(C_{N H 3}\right)$ at $550{ }^{\circ} \mathrm{C}$, for the four studied oxygen concentrations.

\section{Modeling of $\mathrm{NH}_{3}$ responses under different $\mathrm{O}_{2}$ concentrations}

Based on the previous experimental results (Fig. 8), and on the semi-logarithmic behavior of $\mathrm{NH}_{3}$ responses plotted in Fig. 9, a model is proposed to quantify sensor responses. For this modeling, sensor responses in the base gas (considering only electrochemical oxygen reaction) and with $\mathrm{NH}_{3}$ injections (mixed potential theory) are considered separately.

\subsection{Baseline modeling $\left(C_{N H 3}=0\right)$}

For the baseline of the sensor (when $C_{N H 3}=0$ ), an equilibrium condition is assumed for the unique electrochemical reaction of the oxygen (reaction 2 , no mixed potential), so Nernst 
equation is used for calculating the potential of each electrode and finally the electromotive force, which corresponds to the sensor signal $\Delta V_{R E}^{0}$ given by equation 3 . In this relation, $\mathrm{C}_{\mathrm{O} 2}(\mathrm{RE})$ and $\mathrm{C}_{\mathrm{O} 2}(\mathrm{SE})$ should rigorously be the activity of adsorbed oxygen species at respectively the reference electrode $(\mathrm{Pt})$ and sensing electrode $\left(\mathrm{Au}-\mathrm{V}_{2} \mathrm{O}_{5}\right)$ [27]. We made the hypothesis that the activity is equal to the concentrations of the considered species in the gas phase and more specifically the concentration in the gas phase at the three boundary points (electrode $/ \mathrm{YSZ} / \mathrm{O}_{2}$ interface) of each electrode. Since platinum is a highly active catalyst for oxygen reduction (reaction 2), it is assumed that the oxygen concentration $\mathrm{C}_{\mathrm{O} 2}(\mathrm{RE})$ is equal to the oxygen concentration fixed in the gas phase. On the contrary, for the sensing $\mathrm{Au}-\mathrm{V}_{2} \mathrm{O}_{5}$ electrode, due to the lower catalytic activity compared to platinum, the oxygen concentration at $\mathrm{SE} / \mathrm{YSZ} / \mathrm{O}_{2}$ interface will be lower, resulting in varying sensor signals versus oxygen concentration in the base gas $\Delta V_{R E}^{0}\left(C_{N H 3}=0\right)$.

$$
\begin{gathered}
1 / 2 \mathrm{O}_{2}+2 \mathrm{e}^{-} \rightarrow 0^{2-} \\
\Delta V_{R E}^{0}\left(C_{N H 3}=0\right)=E_{O_{2}}(R E)-E_{O_{2}}(S E)=-\frac{R T}{4 F} \ln \frac{C_{O 2}(S E)}{C_{O 2}(R E)}
\end{gathered}
$$

Through Eq. 3 and experimental measurements of $\Delta V_{R E}^{0}\left(C_{N H 3}=0\right), C_{O 2}(S E)$ can be calculated and values are summarized in Table 2.

Table 2 Calculated oxygen concentrations on the sensing electrode at $550^{\circ} \mathrm{C}$.

\begin{tabular}{|l|l|l|}
\hline $\begin{array}{l}\mathrm{O}_{2} \text { concentration in gas } \\
\text { stream } C_{O 2}(\mathrm{RE})(\mathrm{mol} . \%)\end{array}$ & $\Delta \mathrm{V}_{\mathrm{RE}}^{0}\left(C_{N H 3}=0\right)(\mathrm{V})$ & $\begin{array}{l}\text { Calculated } \mathrm{O}_{2} \text { concentration on } \\
\text { sensing electrode } C_{O 2}(\mathrm{SE}) \text { (mol.\%) }\end{array}$ \\
\hline 2 & 0.012 & 1 \\
\hline 5 & 0.009 & 3 \\
\hline 12 & 0.008 & 7.7 \\
\hline 16.4 & 0.007 & 11 \\
\hline
\end{tabular}




\section{2 $\mathrm{NH}_{3}$ responses modeling}

At the electrodes of a typical mixed-potential ammonia sensor $[4,28]$, the reduction reaction of oxygen (reaction 2) competes with the oxidation reaction of ammonia (reaction 4).

$$
2 / 3 \mathrm{NH}_{3}+\mathrm{O}^{2-} \rightarrow 1 / 3 \mathrm{~N}_{2}+2 \mathrm{e}^{-}+\mathrm{H}_{2} \mathrm{O}
$$

A mixed potential is established in steady-state condition when the rates of oxidation and reduction reactions are equal.

According to the mixed-potential theory, the reaction rate-limiting kinetics follow the ButlerVolmer equation, and at high over-potentials, the electric current densities (for electrochemical reactions 2 and 4) can be described by Tafel behavior with Eqs. 5 and 6 [10, 16, 29, 30].

$$
\begin{aligned}
i_{N_{3}} & =i_{N_{3}}^{0} \exp \left[\frac{2 \alpha_{1} F\left(E-E_{N H_{3}}^{0^{\prime}}\right)}{R T}\right] \\
i_{O_{2}} & =i_{O_{2}}^{0} \exp \left[\frac{-2 \alpha_{2} F\left(E-E_{O_{2}}^{0^{\prime}}\right)}{R T}\right]
\end{aligned}
$$

where $E$ is the potential produced by either $\mathrm{NH}_{3}$ oxidation or $\mathrm{O}_{2}$ reduction reactions, $i_{\mathrm{NH}_{3}}^{0}$ and

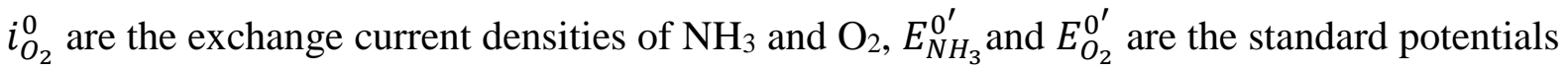
for $\mathrm{NH}_{3}$ and $\mathrm{O}_{2}$ reactions, $\alpha_{1}$ and $\alpha_{2}$ are the transfer coefficients of $\mathrm{NH}_{3}$ and $\mathrm{O}_{2}, T$ is the temperature, $F$ is the Faraday constant, and $R$ is the gas ideal constant.

Supposing that the exchange current densities follow Freundlich isotherm, $i_{\mathrm{NH}_{3}}^{0}$ and $i_{\mathrm{O}_{2}}^{0}$ can be expressed by Eqs. 7 and 8 [10, 16, 29].

$$
\begin{aligned}
& i_{N H_{3}}^{0}=B_{1} C_{N H 3}^{n} \\
& i_{O_{2}}^{0}=-B_{2} C_{O 2}^{m}
\end{aligned}
$$

Where $B_{1}, B_{2}, m$, and $n$ are Freundlich constants, $C_{N H 3}$ and $C_{O 2}$ are concentrations of ammonia and oxygen respectively. When reactions 2 and 4 reach a dynamic balance $\left(i_{\mathrm{NH}_{3}}+i_{\mathrm{O}_{2}}=0\right)$, the mixed potential is established (Eq. 9).

$$
E_{\text {mix }}=E_{0}+m A^{\prime \prime} \ln C_{O 2}-n A^{\prime \prime} \ln C_{N H 3}
$$


Where

$$
\begin{gathered}
E_{0}=\frac{R T}{2\left(\alpha_{1}+\alpha_{2}\right) F} \ln \frac{B_{2}}{B_{1}}+\frac{\alpha_{1} E_{N H_{3}}^{0^{\prime}}+\alpha_{2} E_{O_{2}}^{0^{\prime}}}{\alpha_{1}+\alpha_{2}} \\
A^{\prime \prime}=\frac{R T}{2\left(\alpha_{1}+\alpha_{2}\right) F}
\end{gathered}
$$

As said before, assuming that the platinum electrode behaves like a "real" reference electrode, its mixed potential is close to $0\left(E_{\text {mix }}(\mathrm{RE}) \sim 0\right)$ [21]. Consequently, according to Eq. 12, the signal of the sensor is equal to the negative of the mixed potential of the sensing electrode.

$$
\Delta V_{R E}^{0}\left(C_{N H 3} \neq 0\right)=E_{\text {mix }}(R E)-E_{\text {mix }}(S E) \sim-E_{\text {mix }}(S E)
$$

To calculate the mixed potential of the sensing electrode using Eqs. 9 to 11, estimated values of $\boldsymbol{E}_{\mathbf{N H}_{3}}^{\mathbf{0}^{\prime}}, \boldsymbol{E}_{\boldsymbol{O}_{2}}^{\mathbf{0}^{\prime}}, B_{1}, B_{2}, m$, and $n$ parameters are derived from the literature [31-33]. These values are listed in Table 3.

Table 3 Parameter used for the sensor response modeling, issued from the literature [31-33].

\begin{tabular}{|l|l|}
\hline Parameter & Value (unit) \\
\hline$E_{O_{2}}^{0^{\prime}}$ & $1.22(\mathrm{~V})$ \\
\hline$E_{N H_{3}}^{0^{\prime}}$ & $-0.77(\mathrm{~V})$ \\
\hline$m$ & 0.5 \\
\hline$n$ & 0.885 \\
\hline$B_{2}$ & 0.0642 \\
\hline$B_{1}$ & 0.4227 \\
\hline
\end{tabular}

Then, using the experimental results $\left(\Delta V_{R E}^{0}\right.$ as a function of $C_{O 2}$ and $\left.C_{N H 3}\right)$, and optimizing $\alpha_{1}$ and $\alpha_{2}$ by means of a solver (Excel Solver, minimizing the sum of error squares), all values are determined and listed in Table 4 . The obtained total mean square error is equal to $1.3 \times 10^{-}$ ${ }^{4}$. From these calculated parameters, it is now possible to estimate the sensor signal for different $\mathrm{NH}_{3}$ injections $\left(\Delta V_{R E}^{0}\left(C_{N H 3} \neq 0\right)\right)$.

Table 4 Parameter values issued from experimental results fitting. 


\begin{tabular}{|l|l|}
\hline Parameter & Obtained value (unit) \\
\hline$\alpha_{1}$ & 0.92 \\
\hline$\alpha_{2}$ & 0.32 \\
\hline$E_{0}$ & $-0.312(\mathrm{~V})$ \\
\hline$A^{\prime \prime}$ & 0.029 \\
\hline
\end{tabular}

\subsection{Integration of baseline and $\mathrm{NH}_{3}$ responses modeling}

Finally, the results of data modeling for the baseline $\left(\mathrm{C}_{\mathrm{NH}_{3}}=0\right)$, according to Nernst equation (equation 3) and for different concentrations of ammonia $\left(C_{N H 3} \neq 0\right)$, according to mixed potential theory (equations 5 to 12), are plotted in Fig. 10 along with the experimental data. There is a good agreement between the model estimated from the previous calculations (orange curve) and experimental results (blue curve). Consequently, this validates the proposed model to describe ammonia response of the used single chamber sensor.

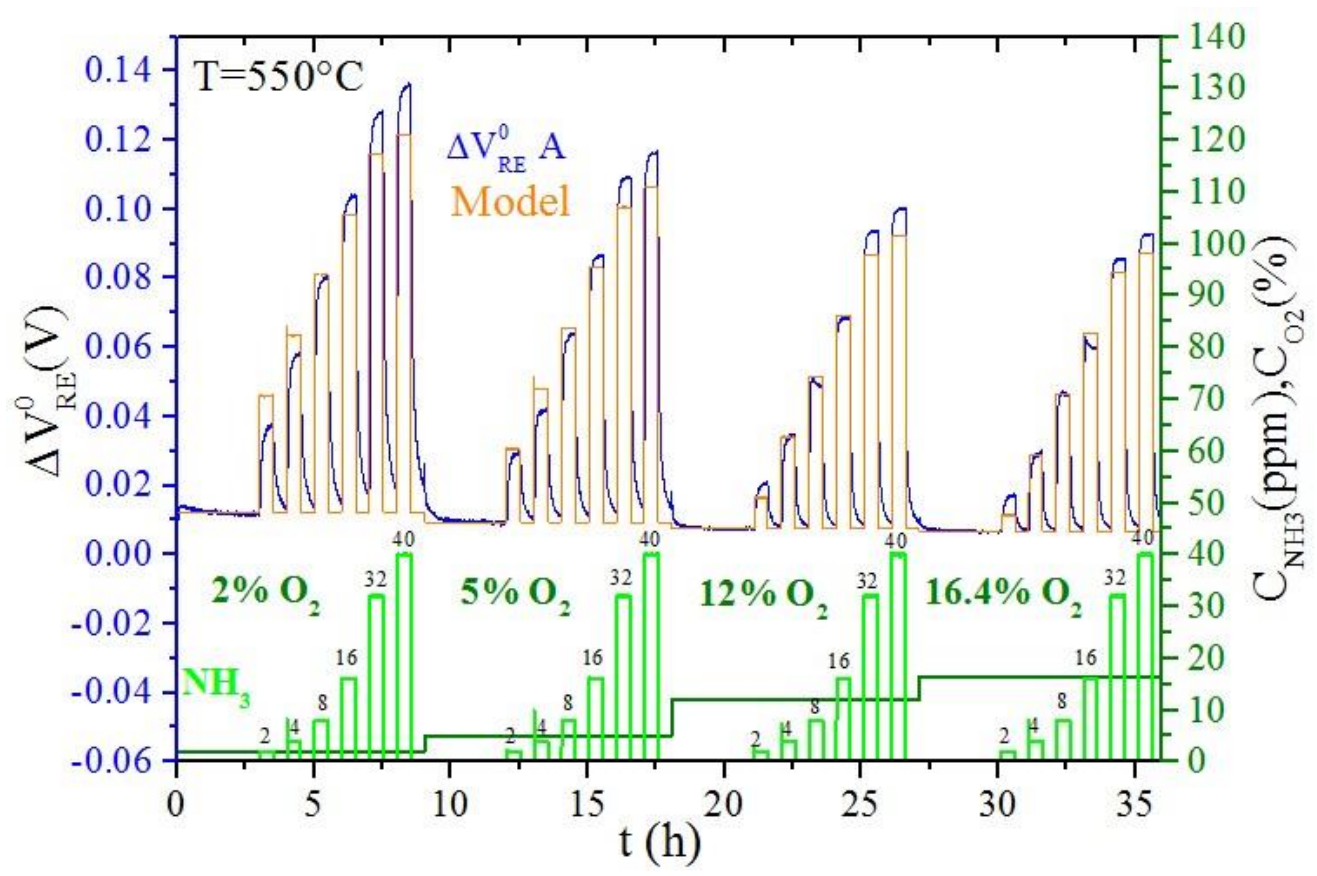

Fig. 10 Comparing modeling and experimental results for $\mathrm{Au}-50 \% \mathrm{~V}_{2} \mathrm{O}_{5}$ sensor to different concentration of $\mathrm{NH}_{3}(2,4,8,16,32$, and $40 \mathrm{ppm})$ and four concentrations of oxygen $(2 \%, 5 \%$, $12 \%$, and $16.4 \%$ ) at $550{ }^{\circ} \mathrm{C}$. 


\section{Conclusion}

For developing a selective mixed-potential ammonia sensor, a vanadium oxide-based material $\left(\mathrm{Au}-\mathrm{V}_{2} \mathrm{O}_{5}\right)$ was tested as sensing electrodes of a two-electrode structure sensor. The results showed that the selectivity of the sensor is dependent on the operating temperature and on the $\mathrm{V}_{2} \mathrm{O}_{5}$ content of the sensing electrode. By increasing $\mathrm{V}_{2} \mathrm{O}_{5}$ content in sensing electrode from $15 \mathrm{wt} . \%$ to $50 \mathrm{wt} . \%$, selective ammonia sensors were achieved at $550{ }^{\circ} \mathrm{C}$ with high ammonia sensitivity around (62 mV/decades for $12 \mathrm{~mol} \% \mathrm{O}_{2}$ in the base gas). The sensors with $\mathrm{Au}$ $50 \mathrm{wt} . \% \mathrm{~V}_{2} \mathrm{O}_{5}$ electrodes showed no cross-sensitivity to $\mathrm{CO}, \mathrm{NO}_{2}, \mathrm{NO}, \mathrm{H}_{2}$ and Hydrocarbons at $550{ }^{\circ} \mathrm{C}$ and also in gas mixtures of $\mathrm{CO}, \mathrm{NH}_{3}, \mathrm{NO}_{2}$, and $\mathrm{NO}$ gases. The obtained responses from this sensor were modeled successfully according to Nernst and Butler-Volmer equations.

\section{References}

[1] L. Dai, G. Yang, H. Zhou, Z. He, Y. Li, L. Wang, Mixed potential $\mathrm{NH}_{3}$ sensor based on Mg-doped lanthanum silicate oxyapatite, Sensors and Actuators B: Chemical. 224 (2016) 356363. https://doi.org/10.1016/j.snb.2015.10.071.

[2] N. Miura, T. Sato, S.A. Anggraini, H. Ikeda, S. Zhuiykov, A review of mixed-potential type zirconia-based gas sensors, Ionics. 20 (2014) 901-925. https://doi.org/10.1007/s11581-0141140-1.

[3] I. Lee, B. Jung, J. Park, C. Lee, J. Hwang, C.O. Park, Mixed potential $\mathrm{NH}_{3}$ sensor with $\mathrm{LaCoO}_{3}$ reference electrode, Sensors and Actuators B: Chemical. 176 (2013) 966-970. https://doi.org/10.1016/j.snb.2012.09.009.

[4] D. Schönauer-Kamin, M. Fleischer, R. Moos, Half-Cell Potential Analysis of an Ammonia Sensor with the Electrochemical Cell $\mathrm{Au}|\mathrm{YSZ}| \mathrm{Au}, \mathrm{V}_{2} \mathrm{O}_{5}-\mathrm{WO}_{3}-\mathrm{TiO}_{2}$, Sensors. 13 (2013) 4760-4780. https://doi.org/10.3390/s130404760.

[5] L. -k. Tsui, A.D. Benavidez, P. Palanisamy, L. Evans, F.H. Garzon, A Three Electrode Mixed Potential Sensor for Gas Detection and Discrimination, ECS Transactions. 75 (2016) 922. https://doi.org/10.1149/07516.0009ecst.

[6] P. Pasierb, M. Rekas, Solid-state potentiometric gas sensors-current status and future trends, Journal of Solid State Electrochemistry. 13 (2009) 3-25. https://doi.org/10.1007/s10008-008-0556-9. 
[7] V.V. Plashnitsa, P. Elumalai, Y. Fujio, N. Miura, Zirconia-based electrochemical gas sensors using nano-structured sensing materials aiming at detection of automotive exhausts, Electrochimica Acta. 54 (2009) 6099-6106. https://doi.org/10.1016/j.electacta.2008.12.040.

[8] W. Meng, L. Dai, W. Meng, H. Zhou, Y. Li, Z. He, L. Wang, Mixed-potential type $\mathrm{NH}_{3}$ sensor based on $\mathrm{TiO}_{2}$ sensing electrode with a phase transformation effect, Sensors and Actuators B: Chemical. 240 (2017) 962-970. https://doi.org/10.1016/j.snb.2016.09.021.

[9] D.Y. Wang, R.J. Robert, C.A. Valdes, E.M. Briggs, K.K. Polikarpus, J. Kupe, W.T. Symons, Ammonia gas sensors, US Patent 7,074,319, 2006.

[10] B. Wang, S. Yao, F. Liu, Y. Guan, X. Hao, X. Liang, F. Liu, P. Sun, Y. Wang, H. Song, G. Lu, Fabrication of well-ordered porous array mounted with gold nanoparticles and enhanced sensing properties for mixed potential-type zirconia-based $\mathrm{NH}_{3}$ sensor, Sensors and Actuators B: Chemical. 243 (2017) 1083-1091. https://doi.org/10.1016/j.snb.2016.12.094.

[11] F. Liu, S. Li, J. He, J. Wang, R. You, Z. Yang, L. Zhao, P. Sun, X. Yan, X. Liang, X. Chuai, G. Lu, Highly selective and stable mixed-potential type gas sensor based on stabilized zirconia and $\mathrm{Cd}_{2} \mathrm{~V}_{2} \mathrm{O}_{7}$ sensing electrode for $\mathrm{NH}_{3}$ detection, Sensors and Actuators B: Chemical. 279 (2019) 213-222. https://doi.org/10.1016/j.snb.2018.09.024.

[12] C. Wang, X. Li, F. Xia, H. Zhang, J. Xiao, Effect of $\mathrm{V}_{2} \mathrm{O}_{5}$-content on electrode catalytic layer morphology and mixed potential ammonia sensor performance, Sensors and Actuators B: Chemical. 223 (2016) 658-663. https://doi.org/10.1016/j.snb.2015.09.145.

[13] D. Schönauer, T. Nieder, K. Wiesner, M. Fleischer, R. Moos, Investigation of the electrode effects in mixed potential type ammonia exhaust gas sensors, Solid State Ionics. 192 (2011) 38-41. https://doi.org/10.1016/j.ssi.2010.03.028.

[14] V.V. Plashnitsa, P. Elumalai, Y. Fujio, T. Kawaguchi, N. Miura, Spontaneous gradual accumulation of hexagonally-aligned nano-silica on gold nanoparticles embedded in stabilized zirconia: a pathway from catalytic to $\mathrm{NH}_{3}$-sensing performance, Nanoscale. 3 (2011) 22862293. https://doi.org/10.1039/c1nr10091b.

[15] A. Satsuma, M. Katagiri, S. Kakimoto, S. Sugaya, K. Shimizu, Effects of Calcination Temperature and Acid-Base Properties on Mixed Potential Ammonia Sensors Modified by Metal Oxides, Sensors. 11 (2011) 2155-2165. https://doi.org/10.3390/s110202155. 
[16] F. Liu, R. Sun, Y. Guan, X. Cheng, H. Zhang, Y. Guan, X. Liang, P. Sun, G. Lu, Mixedpotential type $\mathrm{NH} 3$ sensor based on stabilized zirconia and $\mathrm{Ni}_{3} \mathrm{~V}_{2} \mathrm{O}_{8}$ sensing electrode, Sensors and Actuators B: Chemical. 210 (2015) 795-802. https://doi.org/10.1016/j.snb.2015.01.043.

[17] V. Modafferi, S. Trocino, A. Donato, G. Panzera, G. Neri, Electrospun $\mathrm{V}_{2} \mathrm{O}_{5}$ composite fibers: Synthesis, characterization and ammonia sensing properties, Thin Solid Films. 548 (2013) 689-694. https://doi.org/10.1016/j.tsf.2013.03.137.

[18] A. Morata, J. Viricelle, A. Tarancon, G. Dezanneau, C. Pijolat, F. Peiro, J. Morante, Development and characterisation of a screen-printed mixed potential gas sensor, Sensors and Actuators B: Chemical. (2007) 561-566.

[19] J. Gao, J.-P. Viricelle, C. Pijolat, P. Breuil, P. Vernoux, A. Boreave, A. Giroir-Fendler, Improvement of the NOx selectivity for a planar YSZ sensor, Sensors and Actuators B: Chemical. 154 (2011) 106-110. https://doi.org/10.1016/j.snb.2010.01.033.

[20] I. Romanytsia, J.-P. Viricelle, P. Vernoux, C. Pijolat, Application of advanced morphology $\mathrm{Au}-\mathrm{X}\left(\mathrm{X}=\mathrm{YSZ}, \mathrm{ZrO}_{2}\right)$ composites as sensing electrode for solid state mixed-potential exhaust $\mathrm{NO}_{\mathrm{x}}$ sensor, Sensors and Actuators B: Chemical. 207 (2015) 391-397. https://doi.org/10.1016/j.snb.2014.10.017.

[21] N. Miura, T. Raisen, G. Lu, N. Yamazoe, Highly selective CO sensor using stabilized zirconia and a couple of oxide electrodes, Sensors and Actuators B: Chemical. 47 (1998) 8491. https://doi.org/10.1016/S0925-4005(98)00053-7.

[22] R. Levi, M. Bar-Sadan, A. Albu-Yaron, R. Popovitz-Biro, L. Houben, Y. Prior, R. Tenne, Stability Criteria of Fullerene-like Nanoparticles: Comparing $\mathrm{V}_{2} \mathrm{O}_{5}$ to Layered Metal Dichalcogenides and Dihalides, Materials. 3 (2010) 4428-4445. https://doi.org/10.3390/ma3084428.

[23] K. Gupta, Effect of Post Annealing on the Structural Properties of Vanadium Oxide Thin Film Deposited by RF Sputtering, Indian Journal of Science and Technology. 10 (2017) 1-5. https://doi.org/10.17485/ijst/2017/v10i42/115790.

[24] D. Schönauer, K. Wiesner, M. Fleischer, R. Moos, Selective mixed potential ammonia exhaust gas sensor, Sensors and Actuators B: Chemical. 140 (2009) 585-590. https://doi.org/10.1016/j.snb.2009.04.064. 
[25] J.W. Fergus, Sensing mechanism of non-equilibrium solid-electrolyte-based chemical sensors, Journal of Solid State Electrochemistry. 15 (2011) 971-984. https://doi.org/10.1007/s10008-010-1046-4.

[26] E. Comini, G. Faglia, G. Sberveglieri, eds., Solid state gas sensing, Springer, New York, NY, 2009.

[27] C.O. Park , N. Miura, Absolute potential analysis of the mixed potential occurring at the oxide/YSZ electrode at high temperature in NOx-containing air, Sensors and Actuators B: Chemical. B 113 (2006) 316-319. https://doi.org/10.1016/j.snb.2005.03.010.

[28] R. Moos, J. Kita, Ceramic multilayer gas sensors-An overview, in: XXXI International Conference of IMAPS Poland Chapter, Rzeszów-Krasiczyn, 2007.

[29] F. Garzon, Solid-state mixed potential gas sensors: theory, experiments and challenges, Solid State Ionics. 136-137 (2000) 633-638. https://doi.org/10.1016/S0167-2738(00)00348-9.

[30] T. Ritter, J. Lattus, G. Hagen, R. Moos, On the influence of the NOx equilibrium reaction on mixed potential sensor signals: A comparison between FE modelling and experimental data, $\begin{array}{lllllll}\text { Sensors and Actuators } & \text { B: } & \text { Chemical, } 296 & \text { (2019) }\end{array}$ https://doi.org/10.1016/j.snb.2019.12662

[31] A.A. Halim, H.A. Aziz, M.A.M. Johari, K.S. Ariffin, M.J.K. Bashir, Semi-Aerobic Landfill Leachate Treatment Using Carbon-Minerals Composite Adsorbent, Environmental Engineering Science. 29 (2012) 306-312. https://doi.org/10.1089/ees.2010.0204.

[32] H. Zhang, Y. Wang, Z. Wu, D.Y.C. Leung, An ammonia electrolytic cell with $\mathrm{NiCu} / \mathrm{C}$ as anode catalyst for hydrogen production, Energy Procedia. 142 (2017) 1539-1544. https://doi.org/10.1016/j.egypro.2017.12.605.

[33] P. Vanýsek, Handbook of Chemistry and Physics, 88th ed., 2007. 